\title{
Problematic Approach to English Learning and Teaching: A Case in Indonesia
}

\author{
Himpun Panggabean ${ }^{1}$ \\ ${ }^{1}$ Universitas Methodist Indonesia, Medan, Indonesia \\ Correspondence: Himpun Panggabean, Universitas Methodist Indonesia, Medan, Indonesia. E-mail: \\ himpang_25@yahoo.com
}

Received: October 29, 2014 Accepted: November 30, 2014 Online Published: February 13, 2015

doi:10.5539/elt.v8n3p35 URL: http://dx.doi.org/10.5539/elt.v8n3p35

\begin{abstract}
This article deals with problematic approach to English learning and teaching due to misleading conception on the nature of English and on the process of acquiring it as well as the clues to the issues. The clues are: Firstly, English is not more difficult than any other languages, including Indonesian language, Bahasa Indonesia (Note 1). Secondly, there are two approaches that need considering in English instruction, grammar free and strict grammar approaches. The former is highly recommended for early age instruction and beginners whereas the latter is recommended for instruction for specific purposes. However the two approaches should collaborate and their applications should be based on needs analysis. Thirdly, Conflicting conception on whether L1 and L2 are the same processes should not deter the strategy of how language is acquired naturally. When proper conception on the nature of English is attained and it is approached properly, English subject is not burdensome and needs not be eliminated from Primary School curriculum, and there is no need to reduce time allotment for the subject in Senior High School as stipulated in Indonesian English curriculum amendment.
\end{abstract}

Keywords: acquisition process, context-based and strict grammar approaches, misleading conception, nature of English, psychological burden, purposes

\section{Introduction}

That English as a global lingua franca is increasingly important and even compulsory in all nations throughout the world in order for them to be able to communicate effectively one to each other has prompted the awareness that English must be learned and taught in and outside schools. In Indonesia where I am based, for instance, learning and teaching English is conducted extensively in formal schools beginning from early education to university levels. The fact can be seen in that English is one of a few subjects on which emphasis is given.

The strategy suggests that English as a global language is a second language in Indonesia that hopefully will lead to official use of it as a medium of communication in such domains as government and education. Unfortunately, the hope vanishes following the amendment of 2013 Indonesian English curriculum coming into effect in 2014, in which English subject in Primary School is eliminated and in Senior High School, time allotment for the subject is reduced. The amendment is deemed a serious setback.

The reasons why the new curriculum is implemented are not explicitly stated by the government but according to High School English instructors I teach in a teaching training major at postgraduate program, the reasons are English subject is too hard for Primary School pupils and English subject in Senior High School hampers the students' achievement in Bahasa Indonesia as national language. Such reasons are undoubtedly misleading. It is the wrong conception on the nature of English and how it is taught and learned that makes English subject too hard and there is no link between learning English too much and poor achievement in another language, Bahasa Indonesia.

Due to the misleading conception, the way English is learned and taught bears burden. Despite that since 1980's grammar-based approach has changed into functional use approach in Indonesian English curriculum, the instructors still teach English with grammar-based approach as well as with pronunciation and intonation they deem correct despite that they do not know exactly the correct ones. Consequently, the instructors fail to create fascinating atmosphere of learning and teaching. Because of it, many learners find it burdensome to learn English. In formal schools, many learners think that English is the most difficult subject, even more difficult than 
mathematics, physics, economics, etc. In the absence of clue to the issue, complaints on how English is learned and taught as well as the large amount of time allotted for English subject emerged and mounted up.

The idea that English is the most difficult language of all languages and very much different from Bahasa Indonesia bringing about conflicting conception on which of grammar free or strict grammar approaches is better in learning and teaching English may also be blamed for why many English learners find English instruction burdensome. Indeed, the approach of learning and teaching English may be either one of them or both of them, being dependent on what objectives to pursue.

There are two types of English instruction, namely General English and English for Specific Purposes (ESP) instructions (I don't refer to formal definitions of the two terms rather I use my view that fits the idea of this article). If the learners know the objective of the instruction, they won't find English learning burdensome. According to (Hutchinson et al., 1992, p. 6), the fact that learners know specifically why they are learning a language is a great advantage for teaching and learning process. With this in mind, both instructors and learners should know the objective of instruction before commencing the process of teaching and learning.

\section{The Nature of English}

English is specific for Indonesian people because it is not their language. It is true that English is very different from Bahasa Indonesia in terms of phonology, morphology, and syntax. In the level of pronunciation and orthography, for instance, English speech sounds do not have conformity with graphic signs, unlike Bahasa Indonesia and its sister languages in Austronesian language family. However English is not more difficult than Bahasa Indonesia and vice versa nor is English the most difficult language of all languages. All human languages, including English can be acquired by all normal individuals.

Concerning the fact that there is no language appears to be more difficult to learn and all human beings have capacity to acquire any language, (Jacobs et al., 1968, p. 28) suggest:

Normal infants are born fully equipped to learn any human language spoken anywhere in the world, and all normal children go through more or less the same stages of learning languages, with no language appearing to be more difficult to learn than any other.

Related to the theory is what (Finnegan et al., 1989, p. 15) state:

It is important to recognize that any child who is capable of acquiring some particular human language is capable of acquiring any human language. All children except those with mental or physical impairments acquire their native language in childhood, whatever their culture and whatever their level of intelligence. The ability to acquire language is a fundamental human trait.

It can be inferred that there are no geographical, cultural, and biological boundaries in learning any language in the world. The instructors and learners must realize this and the fact that all normal people, inclusive of them, are born fully equipped to learn and use any human language including English.

Why Indonesian learners find it difficult and take a very long time to acquire English is because they don't make using the language a habit. In fact language competence is attained from habit formation. According to (Panggabean, 2007, p. 160), a native speaker acquires his language because he keeps learning by thinking, listening, and speaking in the language he is learning, meaning he learns the language continuously.

Indonesian speaking learners of English indeed spend very little time using and thinking in English. They are dependent on classroom learning activities that may occur, say twice a week, each of which lasts for one hour. In the classroom, their instructors teaching in traditional method may not involve them profoundly. This means that the actual time spent in one week is less than two hours. Regardless of how many years they have been learning English in this circumstance, the fact is they learn it in weeks instead of years.

In language acquisition process, learning in weeks results in very little achievement. An infant, for instance, begins to shift his babbling production of speech-like sounds to true speech production when he is eight to ten months though he has heard and responsive to adult speech sounds long before it. Only after is he four or five years, when he conducts reinforcement, imitation, and expansion, his utterances are nearly like those of adults (Foss et al., 1978, pp. 234-266).

\section{The Objectives of Instruction and Grammar}

\subsection{English for General Purposes and Grammar}

As stated previously, whether English has to be taught with grammar free or strict grammar approaches depends on what the objective of the instruction is. If the objective is to enable the learners to communicate verbally for 
daily and general objectives (General English), grammar free approach is applicable.

People who do not learn English in formal instruction where listening/speaking, grammar, reading, and writing are approached proportionately have ability to communicate though they do not learn grammar strictly.

In the countries where English is used as a second language such as Malaysia and Singapore, people can communicate in English though they learn the language without learning grammar. Unlike Indonesian people learning English in formal instruction using strict grammar approach, they learn the language just the way they learn their mother tongues.

In order for Indonesian people to be able to communicate in English like Malaysians and Singaporeans, they should learn English just the way Malaysians and Singaporeans do. Unfortunately, Indonesian learning atmosphere is different from those of in Malaysia and Singapore. Why Malaysians and Singaporeans can learn English naturally is because of the situation that prompts them to use English, such as government policy establishing English as a second language, large number of English speaking tourists visiting the countries, education requirement, internet-based communication, and commercial transactions. In Indonesia, English is not a second language rather a foreign language and its use is not as important as it is in Malaysia and Singapore. With this in mind, it is important that English be formally declared as a second language in Indonesia and that more English speaking people visit the country. It is worth knowing that Malaysians and Indonesians have the same capacity in acquiring English because the national languages of both of people are sister languages, descendents of proto-Malay Polynesian. What make their acquisition processes different are the atmosphere and the way English is taught and learned.

If English were a second language in Indonesia, the way it is learned could be the same as that of in Malaysia and Singapore. What needs to be learned from the way Malaysians and Singaporeans learn English is that the authentic context where English is spoken beyond classroom regardless of ungrammaticality rid them of fear of making mistakes. Despite mistakes, they can use the language creatively for daily purposes.

This kind of learning process is the condition that needs to be created. It is understandable that it takes time to create the same atmosphere in Indonesia but there must be awareness that Indonesian people should start learning English outside classroom. They don't need to be reluctant of using English because of fear of making mistakes in grammar, pronunciation, and intonation. It is out of the question that English of Indonesians is the same as that of native speakers'. Like Malaysians and Singaporeans and other people speaking English as a second language, Indonesians need to develop an English variety, Indonesian English.

Regarding English varieties known as Englishes, (Mohanraj, 2013, p. 45) states:

It is no longer necessary to look up to the British or the American variety as our models to be followed. We may have our own indigenous varieties that suit our purposes.

Indonesian English that may not be grammatical will be easily acquired by Indonesian people since it is learned just the way Singaporeans and Malaysians Englishes are learned by people in Singapore and Malaysia. When this process of acquisition occurs outside classroom, it can be brought to classroom teaching and learning process.

In class activity, the instructors should conduct Communicative Language Teaching (CLT) by exercising experiential learning, negotiated materials, and learners-based instruction. Experiential learning based on what the learners learn outside classroom in authentic context should be made as sources of materials because learners' knowledge of the subject matter enables them to identify a real context for the vocabulary they use. This strategy guarantees learners-based instruction that will motivate the learners to experience self-discovery of English.

This is how genuine or authentic language should be learned and taught. The words, phrases, clauses, and sentences of a language, in this regard English, may not conform to the rules defined by a particular grammar of English but accommodates function and meaning, the ends of communication.

Indonesian speaking learners of English tend to use to be (is, am, and are) regardless of different tenses and types of sentences they build up, for being unable to distinguish them from the other auxiliary verbs. In spite of it, their sentences are understandable since they are used in relations to context. If learners make such mistakes in classroom, the instructors do not need to blame them and spend much time and energy to make correction until all mistakes are completely corrected. This kind of strategy not only is time consuming but also deters how language is acquired naturally.

Following this are the instances of arbitrary uses of to be. 
a) I am study English. *

b) Is your professor know me?*

c) They are eat already lunch. *

d) You are my friend.

The speakers know how to construct the sentences because they know the context and words instead of strict grammar composing them. They do know the loose grammar of the sentences but they do not learn it deliberately rather intuitively just the way they know the grammar of Bahasa Indonesia.

Suppose that the speakers had to learn grammar, they would not gain such communicative end in a given time, for they would spend more time and reasoning to understand and implement the rules of grammar used to structure the symbols.

It is worth realizing that the learning process of language is not bound by learning grammar deliberately. For instance, a native speaker of English will intuitively know how to respond to somebody's statement, I like pizza so much by saying So do I (unmarked statement) instead of I like pizza so much, and So am I*(marked and ungrammatical statements) though he does not learn grammar.

The following dialogues quoted from (Halliday, 2004, pp. 4-169) sound ungrammatical and unusual from the lens of strict grammar.

Dialogue (1)

Dano: I don't want a shower; I had one yesterday.

Father: Oh, I have one every day, Dano, every single day.

Dano: Every single day?

Father: Yeah. So does Mum. Don't you?

Mother: Usually.

Dano: Usually? See, Dad?

Father: Well, usually means mostly, doesn't it, Mary?

Mother: It means more than not.

Dialogue (2)

A: 'Oh I've heard about this.'

B: 'Have you heard about it.'

A: 'Friends have been there.'

B: 'It is the most wonderful wonderful place. Fabulous.'

Despite ungrammaticality and unnaturalness, the two dialogues are authentic speeches which are loosely structured. In Dialogue (1) Yeah. So does Mum. Don't you? is not grammatical, because Don't you? Is not based on the main clause, You have shower every day and not addressed to the questioner. Usually? See, Dad? are not either grammatical, for they don't have subjects. Besides, in the dialogue, some pieces of information are missing. Usually lacks of explicit information that the mother usually has shower.

In Dialogue (2), though the sentences, but It is the most wonderful wonderful place, is grammatical, the question, Have you heard about it? does not have to do with the answer Friends have been there and it is the most wonderful wonderful place. Fabulous. There seems to be digressions in the dialogue in the surface structure.

However, all speeches in the dialogues are authentic thanks to the fact that they are functional and their lacking of elements has been covered by the contexts of speeches. The context in the dialogue is as follows: In Dialogue (1), the text involves Dano, Father, and Mother (Mary) in a family dialogue. In Dialogue (2), there is context understood by the speakers namely a place called Surai in East Bali, Indonesia. Since there are mutual intelligibilities in the texts, the speeches are undoubtedly genuine. Consequently, even though the above speeches are ungrammatical or loosely grammatical, they are adequate and meet what each of the speakers has in thought and achieve the communication goal.

In actual communication, besides ungrammaticality unclear relationships among utterances as seen in the following dialogue quoted from (Levinson, 1983, p. 97) frequently arise.

Dialogue (3) 
A: Can you tell me the time?

B: Well, the milkman has come.

Pragmatically speaking, the dialogue can be paraphrased as follows:

A: Do you have the ability to tell me the time?

B: [pragmatically interpreted particle] the milkman came at some time prior to the time of speaking

Though in the dialogue, the first and the second sentences are grammatical, the grammar of the first does not fit that of the second. Can you tell me the time? requires Yes I can or No I can't. Despite the ungrammaticality and unclear relationships between one from another, this kind of dialogue is natural.

The models of the above texts when introduced to English learners, especially the beginners, will facilitate and encourage them to learn the language the way the native speakers do. Being used to the model, they are free from fear of making grammatical mistakes and find learning English exciting.

With this in mind, English class can be designed in a model that accommodates foreigners' traits of learning a second language characterized by social and cultural communication. In this case, the English used by learners must be impacted by social, cultural, and linguistic backgrounds of their own. This means that English instruction does not necessarily bear psychological burden nor is it too hard to be learned by even Primary School pupils.

For Primary School pupils, the materials to be introduced stem from what they can see every day in classroom and their neighborhood, the names of their subjects, their daily activities, and the other things common to them. For this purpose, classroom needs to be provided with pictures.

More importantly, English in this early age should be taught for fun just like songs are sung and games are played, being different from how other subjects, say mathematics and physics, are taught. Consequently, strict grammar is not necessarily introduced. It is not expected that the learners must construct grammatical sentence such as He learns English instead of He is learn English*. What is important is the learners begin feeling in mood to use English in early age, the best period to acquire second language.

Learning second language in early age is highly recommended. To support this, it is important to keep in mind The Critical Period Hypothesis proposed by (Penfield et al., 1959), that the optimum age for acquiring another language is in the first ten years of life because it is then that the brain retains its maximum plasticity or flexibility. At around puberty, the brain loses its plasticity after which acquiring another language becomes increasingly difficult.

Based on the argumentation, there is no need to eliminate English subject from Primary School curriculum in Indonesia. The government had better change the conception on English and the way it is learned and taught rather than eradicate it from curriculum.

\subsection{English for Specific Purposes and Grammar}

Strict grammar approach, as put forward previously, should be implemented if the objectives of the instruction are specific purposes, English for Specific Purposes (ESP), for instance, English for Academic Purpose, English for Journalism, English for Formal Writing Document, English for Formal Events, English for Broadcasting, and preparation for English test as international language such as Test of English as a Foreign Language (TOEFL), International English Language Testing System (IELTS), and Test of English for International Communication (TOEIC). However, not all English instructions for specific purposes should be approached with strict grammar. For instance, English for tourism and hotel as well as English for medicine instructions do not require strict grammar approach, for what is required in these fields is the competence to convey pieces of information dominated by technical terms.

In learning English for specific purposes requiring strict grammar, learners who have learned general English will benefit from their experiences of learning general English in context-based approach in terms of vocabulary, grammar, and subject matter. When enough time is available, audioligualism methodology in which rules are caught rather than taught, can be applied. This methodology is applied, according to (Nunan, 1999, p. 77) by exercising the following principles:

1) Language learning is a process of habit formation.

2) Teachers should teach the language, they should not teach about language.

It is true that habit of using language leads learners to applicable proficiency of grammar. My former student when starting working as a translator in a Consulate had bad structure of English. After working for a few 
months and keeping translating materials from Bahasa Indonesia into English, his grammar tremendously improved. The habit he had is much more powerful than his learning grammar in formal class of grammar I taught for three semesters. Based on the experience, I motivated my students to write any issue they are interested in as supplement to formal course of grammar. Surprisingly, five out of twenty got their articles published in English newspaper after they repeatedly revised them. Clinging to formal instruction, they would not be able to write articles in English newspaper where grammar use is very strict.

However, when time allotment for instruction for certain purposes, is limited, habit formation is almost impossible. For instance, if a class is conducted for learners who plan to take international English test, say TOEFL, to gain high score via habit formation is almost impossible. Problems in this kind of test are highly advanced and complex and cover many types of English patterns.

To make the learners get used to using the forms of I would rather that he came early on Saturday, I insist that she be invited, and They object to considering quitting working, for instance, is very difficult. It takes learners very long time to achieve this kind of grammar proficiency. All can be done is to apply grammar-based methodology by introducing problems and solutions. So, if this is the specific purpose of instruction, instructors should focus on how the learners can build up correct words, phrases, and sentences based on the rules of English structure, and motivate them to do off classroom assignment.

The following definition put forward by (Cobbett, 1819) fits this approach.

Grammar...teaches us how to make use of words; that is to say, it teaches us how to make use of them in the proper manner...to be able to choose the words which ought to be placed, we must be acquainted with certain principles and rules; and these principles and rules constitutes what is called Grammar.

The two different circumstances above show that modern teaching approaches such as CLT and audioligualism methodology and traditional grammar-based approach have to coexist and collaborate.

In many English instructions, such collaboration does not apply. Some instructors apply grammar-based approach by ruling out meaning and use (functional use), the other apply function or context-based approach by neglecting the grammar.

In Indonesia, in English curriculum before 1980's, the approach of learning and teaching English was heavily based on grammar where learners' proficiency was based on grammar proficiency and English materials were dominated by grammar and beginning early 1990's the approach shifted to function-based approach where English grammar materials are accommodated by reading and conversation.

The approaches are too extreme. Ideally, there must be collaboration between grammar-based and function-based approaches. Grammar-based approach is required to meet specific purposes as mentioned previously and context-based approach is required to acquire English naturally. Shortly speaking, there should be needs analysis.

Grammar-based approach has strengths, namely its sustainability to standardize language and its agreement with three theories of truth namely, correspondence theory, coherence or consistency theory, and pragmatic or utility theory. For instance, the truth of rule that in present tense sentence, when a verb directly follows the third person singular, the verb must be in -s/es ending as in He smiles and He goes, may be proved by the same patterns of sentences uttered and written by native speakers of English. Meanwhile, it is said that the grammar has agreement with coherence or constancy theory of truth, because the rule, say the above rule, is coherent or consistent with what has been acknowledged to be true. Language rule has also agreement with pragmatic or utility theory of truth because it works to meet language users' need.

Besides, the strength of grammar-based instruction is indicated by its capacity to deal with various intricate issues and thoughts such as those in subjunctive and conditional sentences. Since grammar-based instruction guarantees grammar proficiency, the learners attaining it will have excellent style of using English. Somebody who has vast vocabulary without adequate grammar cannot use English as communicatively as somebody whose vocabulary is vast and whose grammar is excellent, can.

Besides, grammar proficiency opens room for various uses of English language, making it possible for the language users to speak about complex issues communicatively as well as to write manuscripts, books, novels, newspapers, laws, memorandums, and the like. In addition, it contributes completely to the evaluation of level of language proficiency, particularly writing proficiency. Section Structure and Section Reading of TOEFL currently widely used is a concrete evidence of how significant strict grammar instruction is. Practically speaking, why this article is worth publishing is primarily due to the implementation of English language rule in organizing and expressing its ideas. 
However, when instruction gives excessive load to grammar without considering social context of language use, artificial speech will emerge. Sentence My pen is pregnant which does not exist in real world and I kicked the ball with my feet that is pleonasm are grammatically true because they correspond with rules that are applicable, for instance, in My pen is expensive and I broke the wall with stone.

Regarding pleonasm, (Cruse, 1980, p. 45) remarks that pleonasm is a redundancy. The redundancy, in my opinion, is partly due to the fact that pleonasm is grammatically true though redundant.

Because of grammar-centered approach, many English materials are not natural. In this regard, English is learned in the method of how natural sciences are learned instead of how languages are learned.

The unnatural grammatical speech can be clearly observed in dialogue materials of English teaching and learning made up by authors in accordance with formalized rules of language. Consider the following dialogues quoted from (Cornelius, 1979, p. 31; Sharpe, 1997, p. 591-592)

Dialogue (4)

Jenny: What day is it?

Helen: Today's Wednesday, March the twenty-fifth.

Speaking of dates, when are you leaving?

Jenny: I'm leaving on the sixteenth of April.

Helen: Isn't the sixteenth a Wednesday?

Jenny: No. it's a Thursday.

Helen: So you're leaving three weeks from tomorrow...

Jenny: Right

Dialogue (5)

Man: Hi, Margaret. This is Gary.

Woman: Oh, Hi, Gary. Where have you been? I've missed you in lab.

Man: I've been sick.

Woman: Nothing serious, I hope.

Man: Well, I stayed out of the hospital, but to tell the truth, I was in pretty bad shape. Some kind of flu.

Woman: Let's see, how many labs have missed?

Man: Margaret, I got sick three weeks ago, so I am really behind.

Woman: Let me look at my notebook. I've got it right here.

Man: Oh, great. I was hoping you'd let me make a copy of your notes.

Woman: Sure. You can do that, Gary...

The sentences in the two dialogues that are completely grammatical and almost do not miss even a single piece of information sound exactly the same as written forms. It occurs because the dialogue designs ignore relations between Jenny and Helen and between Man and Woman as well as their understanding of the issues of the dialogues called co-text or context. Such complete mentions and absolutely true grammar as shown do not occur in actual social communication. That means that the dialogues meant to be taught and learned in context of genuine or natural speech are not genuine or natural at all. This inhibits the process of how language is learned by its native speakers from babyhood through adulthood.

Regarding the difference between spoken language and written language, it is important to notice what (Finegan et al., 1989, p. 376) state,

Though it is commonly said writing is speech written down or that writing is visual language as distinct from audible language, writing and speaking ordinarily serve different purposes and have somewhat different linguistic characteristics.

Excessive concentration on grammar can neglect that language keeps changing. In today's English, Your health we care derived from We care for your health is now regarded to be grammatical. Formerly, the correct preposition before name of month was on as in on July. Now both on and in are deemed correct. This is to show that grammar changes. There should be modification of rule to accommodate the dynamism. In terms of variants 
of English, new variants emerge since English is not only the language of American and British people but also of almost all inhabitants of the universe. The variants automatically result in need of new rules. Unfortunately, grammaticality of all variants is determined on the basis of rules of American and British English though the other English variants which do not conform to the rules are effective to convey thoughts of the users. Thus, rules of English need extending.

\section{Ideal Position of Grammar}

Based on what has been explained previously, for general and practical purposes, daily communication, and in early age, grammar needs not be taught and learned while for specific purposes it has to be taught and learned.

That grammar is not learned and taught does not mean that the learners do not know grammar. If we conceptualize the learners learning a second language in context-based atmosphere where they are not exposed to grammar, the same as infants learning their mother tongue, they have knowledge of grammar, even though it is tacit, just like the infants do. (Foss et al., 1978, pp. 278-279) state,

...The evidence also suggests that children are acquiring, among other things, a set of rules. This is implied by the fact that the utterances children produce are systematic, as are many of the errors they make. In addition, the nature of the changes in children utterances as language development progresses the development of rules.

This kind of knowledge gained intuitively in general English instruction should be treated as a base of learning grammar in an English instruction for specific purposes. However, though grammar is taught and learned explicitly, the ideal approach is the combination of context-based approach and strict grammar approach. Strict grammar approach may be carried out in authenticity-like approach as in studying language in context by motivating the learners to implement the rules of language they learn in actual spoken and written speeches of which complexity requires knowledge of grammar.

It may be stated that learning English without explicit grammar instruction is very good for general purposes and beginners but it takes a very long time to achieve grammar competence for specific purposes such as academic writing, formal writing, broadcasting, and formal speech in which grammar competence is absolutely required. On the basis of it, there is no need to make the two approaches problematic.

The collaboration of the approaches on the basis of needs analysis prevents proponents of strict grammar approach from boldly criticizing grammatical mistakes of natural speech and emerging Englishes speech. Also, it prevents proponents of context-based approach from paying no attention at all to the importance of grammar. If instruction is completely centered on grammar, particularly in class of beginners, it will be boring, difficult, and hard, for it will be taught just the way mathematics is taught, for instance.

Up to the present, that English is similar to rule still negatively affects English teaching and learning process in Indonesia although English curriculum has adopted functional grammar approach. This is why English subject material in High School is very complex. Consider the following problem quoted from (SNM-PTN IPC, 2009, 2010, p. 17) where the students are asked to choose the best answer.

"Does Anto know that Myrna had an accident yesterday?"

I don't think so. We... as soon as we were informed."

A) May have told him.

B) Should have told him.

C) Had to tell him.

D) Must have told him.

E) Had better tell him.

For Senior High School students, this problem is too difficult. Overestimation of grammar has prompted the designer of the problem to tailor such complexity. He seems to concentrate on making the students find it difficult to answer the grammar problem instead of evaluating how much the students understand the message in the dialogue. Due to the overestimation, the designer writes the options wrongly. Each of the first letters of the first word in the options is capitalized and ended with full stop.

It is possible that the students are able to answer the question correctly but the ability could be based on speculation or learning by heart rules of grammar. If this is the case, the objective of English instruction is no longer communicative values and ends rather aptitude. This is exactly the same as doing the problems of mathematics and physics. 
The instruction aimed at achieving aptitude is time consuming, for the students are not able to implement their knowledge in actual spoken and written communication. At university level, they won't deal with such complex structure. English instruction materials at university are just as simple as, if not simpler than, that of at Junior High School. The education policy makers seem to be indifferent or unable to see the unbalance.

Meanwhile, contextualization itself may lead language users to use language just the way they want in the absence of guide or standard. When it takes place, there will be no grammatical correction on the ground that it is how language users' experiences are represented, related, exchanged, and organized. Though contextualization must be considered in every text, in formal speech and document, academic writing, etc., grammaticality is chiefly required. It will be ridiculous, for instance, if a president talks in ungrammatical phrases, clauses, and sentences or laws are written in ungrammatical sentences.

On the basis of this, contextualization needs to be supported by grammar rules. It means that the approaches are two sides of a coin. Strict grammar provides guide to standardization and context drives the guide to meet context of speech.

In terms of teaching and learning process, the English materials in text books in Indonesia, especially those of dialogues, need modifying by considering balance between context and rules of language, based on needs analysis. The two approaches may be introduced on condition that there must be explanations on the natures of the two types of speech and how important to know them. Second language learners need to understand that why loosely structured or ungrammatical texts are uttered by native speakers of the language is not due to their unknowing how to utter the complete and grammatical ones rather to adjust to context. This is to bridge the gap between learning language relying completely on context without considering rule and learning language and relying completely on rules without considering context.

Collaboration of the approaches is of great importance to bring about better study of language. Combining rules and context of which co-existence is inevitable in actual world should trigger revision of extremely and completely rule-centered and context-centered materials of English text books for the sake of better teaching and learning language process as well as understanding formal and informal events where language is used.

\section{Difference of L1 and L2 Acquisitions}

Misleading understanding on whether first language (L1) and second language (L2) can be acquired in the same process may deter teaching and learning English. It is important to understand that native speakers learn and acquire their languages in natural context. Like native speakers, non-native speakers can learn the second language the same way as it is when authenticity-based communication instruction is created in classroom. More importantly, as said previously, all normal people have innate capacity to acquire any language.

Regarding the problem, there are conflicting ideas on whether L1 and L2 acquisitions are the same process. In regards to similarity, (Nunan, 1999, p. 38) states:

I looked in particular at the perception of semantic and discourse relationships in written texts, and found a high level of agreement between first and second language readers.

Meanwhile, in regards to difference, (Dulay et al., 1974, p. 225) say,

We can no longer hypothesize similarities between L2 and L1 acquisition as we did at the outset of our investigations. Although both L2 and L1 learner reconstruct the language they are learning, it is intuitive to expect that the manner in which they do so will differ. Children learning a second language are usually older than L1 learners; they are further along in their cognitive development, and they have experienced a language before. These factors should combine to make specific strategies of the creative construction process in L2 acquisition somewhat different from those of creative construction process in L1 acquisition.

Despite the difference between them, it should not be overestimated because it can result in psychological burden. Nor should it avert instructors from creating authenticity-based atmosphere resembling the way they acquire their L1. Learning L2 the way learning L1 is much better than learning it in different way.

The capacity possessed by English native speakers is also possessed by learners of English if they learn the language the way the native speakers do. The learners can benefit from the conception by eliminating attitude that English is the most difficult language of all languages and has to be approached scientifically.

When the fact that natural learning language is not bound by complex rules and that the ability of acquiring language is human's trait gained intuitively, are actualized, the process of teaching and learning will lead to learners' self-confidence and the learners will enjoy learning.

The following is my experience of acquiring three languages, Hata Batak (Note 2) (Toba Batak language), 
Bahasa Indonesia as a national language, and English. I acquired Hata Batak as my mother tongue or L1 just the way native speakers of all languages do. When I was six until eighteen years old, I learned Bahasa Indonesia in Primary School through Senior High School in formal instruction of Bahasa Indonesia subject. Since the language was not spoken outside classroom, though I learned it for almost twelve years, my language was poor, particularly in speaking. Only after moving to a city where Bahasa Indonesia was spoken as a lingua franca could my language improved gradually.

As for English, I began learning it in formal instructions at Junior High School through university where I majored in English. In spite of that I learned English for ten years, like my Bahasa Indonesia, my English was poor, particularly in listening and speaking, because I learned it in a city where English was not spoken outside classroom. Being faced with the condition in which I could not learn English in a neighborhood where people spoke English, I regularly visited an English speaking tourists' destination to practice English, joined English speaking church service, listened to English songs, and watched English programs on television. The endeavor resulted in tremendous improvement of my English leading to ability to communicate effectively with English native speakers.

The experience reveals that I did not benefit much from learning Bahasa Indonesia and English in schools and university. It is the authentic social contexts where the two languages are naturally used that enabled me to acquire them. In other words, I succeeded in acquiring the two languages after I found out neighborhoods exactly the same as the neighborhood where I acquired my mother tongue. This is to say that the best instruction in learning both L1 and L2 is social context and L1 and L2 can be acquired in the same process. With this in mind, that specific strategies to learn L2 are required as stated previously by (Dulay et al., 1974, p. 225) is groundless.

However, to gain advanced proficiency in order to be able to debate, deliver speech, write articles as well as understand English newspapers, magazines, and various English sources, I accessed English grammar, dictionaries, and linguistics. This means to say that the proficiency I gained from context-based approach is strengthened by learning grammar and linguistics to create my current competence.

It is worth revealing that my Hata Batak and Bahasa Indonesia, and English acquisition processes do not obstruct one another. The processes of acquisitions work independently and simultaneously despite that sometimes my English is interfered by the two languages. The more I am used to English, the less interference takes place. In my current competence, my English is no longer interfered by the two languages. Currently, all three languages seem to be the same to me.

Since the acquisitions of my English does not hamper my fluency in Hata Batak and Bahasa Indonesia, it can be inferred that English subject hampers the achievement of Bahasa Indonesia in Senior High School in Indonesia is baseless. On the basis of it, time allotment for English in Senior High School needs not be reduced.

\section{Conclusion}

Misleading conception on the nature of English and how they are learned and taught result in mounting complaints is deemed to have lead to amendment of 2013 English curriculum in Indonesia. Because of the misleading conception that English is the most difficult language along with ambivalent stance on whether English should be approached with grammar free or strict grammar approaches as well as whether learning it with specific strategies or the same process as learning first language, English instruction is not satisfactory.

English is not more difficult than Indonesian language, Bahasa Indonesia and the other languages. Why Indonesian speaking learners of English find it difficult and take a very long time to acquire English is due to limited time spent to learn it, using English is not habit. When knowing the nature of English, the learners will not find the instruction burdensome and difficult.

For beginners and English instruction for general purposes, daily communication, grammar free approach is effective because this is how language is naturally acquired by native speakers in social context. Learners in early age, the best time to acquire a second language, should learn English for fun. With this in mind, there is no need to eradicate English subject from Primary School curriculum.

However, for specific purposes, academic need, news writing, formal document writing, formal speeches, and test preparation of English as international language, strict grammar approach needs implementing because knowledge of grammar gained from context-based approach is not adequate. On the basis of it, the approaches should collaborate and their application should be based on needs analysis.

Excessive focus on grammar results in unnatural language and leads instruction to aptitude achievement whereas excessive focus on contextualization deters learners to improve their grammar proficiency that can benefit them when they want to pursue specific purposes. 
English text books need revising by considering balance between context and grammar to enhance the quality of instruction.

Despite difference between first and second language acquisitions, it should not impact negatively learners' strategy of acquiring English in the way they desire. Empirical experience suggests that learning English in actual world where English is spoken is much better than learning it in formal instruction tailored for second language learners in school and university.

L2 acquisition does not obstruct L1 competence. Thanks to it, there is no need to reduce time allotment for English subject in Senior High School.

\section{References}

Cobbett, W. (1819). A grammar of the English Language. Oxford: Oxford University Press.

Collins English Dictionary —Complete and Unabridged. (2003). Harper Collins Publishers.

Cornelius, Jr. E.T. (1979). New English Course 2. San Fransisco: San Fransisco State University.

Cruce, D. A. (1980). Meaning in Language, an Introduction to Semantics and Pragmatics. Oxford: Oxford University Press.

Downing, A., \& Philip, L. (1992). A University Course in English Grammar. Hertford. Hertfordshire: Prentice Hall International (UK) Ltd.

Dulay, H., \& Burt, M. (1974). Natural sequences in child second language acquisition. Language Learning, 24.

Finnegan, E., \& Besnier, N. (1989). Language, its structure, and use. Sandiego: Harcourt Brace Jovanich.

Foss, D. J., \& Hakes, D. T. (1978). Psycholinguistics. New Jersey:Prentice Hall. Inc.

Halliday, M. A. K. (2004). An Introduction to Functional Grammar. London: Arnold.

Hutchinson, T., \& Waters, A. (1987). English for Specific Purposes: A Learning-centered approach. Cambridge: Cambridge University Press.

Mohanraj, S. (2013). Teaching English in Today's World (Proceedings). 2013 International Conference. Bandar Lampung: UBL.

Nunan, D. (1999). Second Language Teaching \& Learning. Boston, Massachusetts: Heinle \& Heinle Publishers.

Levinson, S. C. (1983). Pragmatics. Cambridge: Cambridge University Press.

Panggabean, H. (2007). How to Motivate English Learners Faced with Psychological Burden. K@ta, 9, 158-168. Surabaya: English Department, Faculty of Letters, Petra Christian University.

Panggabean, H. (2014). Reconstruction and Sub-grouping of Batak Languages. IOSR Journals, 18(6), 35-53.

Pemantapan Menghadapi SNM-PT IPC-2010. (1999). Bandung: CV Yrama Widya.

Penfield, W., \& Roberts, L. (1959). Speech and Brain Mechanisms. New York: Atheneum Press.

Sharpe, P. J. (1997). TOEFL. Jakarta: Binarupa Aksara.

\section{Notes}

Note 1. Bahasa Indonesia $n$. The official language of Indonesia: developed from the form of Malay formerly widely used as a trade language in South East Asia (Collins English Dictionary-Complete and Unabridged, 2003).

Note 2. Batak languages are composed of Toba language, Simalungun language, Pakpak Dairi language, Angkola language, Karo language, and Mandailing language spoken in North Sumatera, Indonesia (Panggabean, 2013, p. 35).

\section{Copyrights}

Copyright for this article is retained by the author(s), with first publication rights granted to the journal.

This is an open-access article distributed under the terms and conditions of the Creative Commons Attribution license (http://creativecommons.org/licenses/by/3.0/). 